\title{
RECLAIMING LAND, RECLAIMING GUARDIANSHIP: THE ROLE OF THE TREATY OF WAITANGI AOTEAROA, NEW ZEALAND
}

\author{
Garth Cant,
}

\author{
Toi tu te marae o Tane \\ Toi tu te marae o Tangaroa \\ Toi tu te iwi
}

\section{Aotearoa/New Zealand in Context}

The geographical context is a long, narrow and mountainous land, broadside on to the westerly variables, the coldest and most distant part of Polynesia; discovered and settled a thousand years ago by the ancestors of Maori people, discovered again and, over the last 153 years, colonised by the ancestors of pakeha people (Figure 1). The culture and political context is two peoples, unevenly and ambiguously linked by a treaty signed in 1840 , struggling to work out new resource and decision making relationships in the 1980s and 1990s.

Tipene O'Regan, historian, negotiator, Chairman of the Ngai Tahu Maori Trust Board and presenter of the television series Manawhenua, draws deeply on traditional and academic knowledge to unroll the experience of the Polynesian encounter with this new and distant land. ${ }^{1}$ The ancestors arrived from a world of tropical seas and small islands where Tangaroa, the Atua of the oceans and the fishes, was bountiful. They carried with them very intentional cargoes of people, plants and animals; artefacts; technologies in the mind; spiritual wisdom in the legends, the prayers and the genealogies. The ancestors landed adjacent to bays, river mouths, lagoons and estuaries; they explored, named and came to grips with the new environment by unrolling their legends on the new landscape, by exposing their plant and animal materials to the cold and the seasons and by adapting their technologies to new opportunities. The world of Tangaroa provided more familiar bounty; by contrast the world of forests, birds and insects - the extended family of the Atua Tane provided new bounties and new problems of seasonal food supply. The environmental lessons were gradually learnt and the new world interwoven with tribal and subtribal identity. Long before the arrival of Tasman and Cook, the Maori iwi and hapu, tribes and subtribes, were established as those who nurtured and were nurtured by the land. They were tangata whenua, people of the land; they were the peoples who exercised kaitiakitanga or guardianship over its resources and its stories.

These islands were also the last and most distant outliers of European exploration and settlement. Abel Tasman arrived from Batavia in the Netherlands East Indies in 1632 and placed New Zealand on the global map (Figure 2). James Cook and Jean de Surville both

Garth Cant, from the Department of Geography, University of Canterbury, Christchurch, New Zealand, teaches a graduate course on Indigenous Land Rights in New Zealand, Australia and Canada. He presented an earlier version of this paper to the Canadian Association of Geographers Conference in Carlton, Ottawa.

O'Regan 1987, 1989; Orbell 1985. 

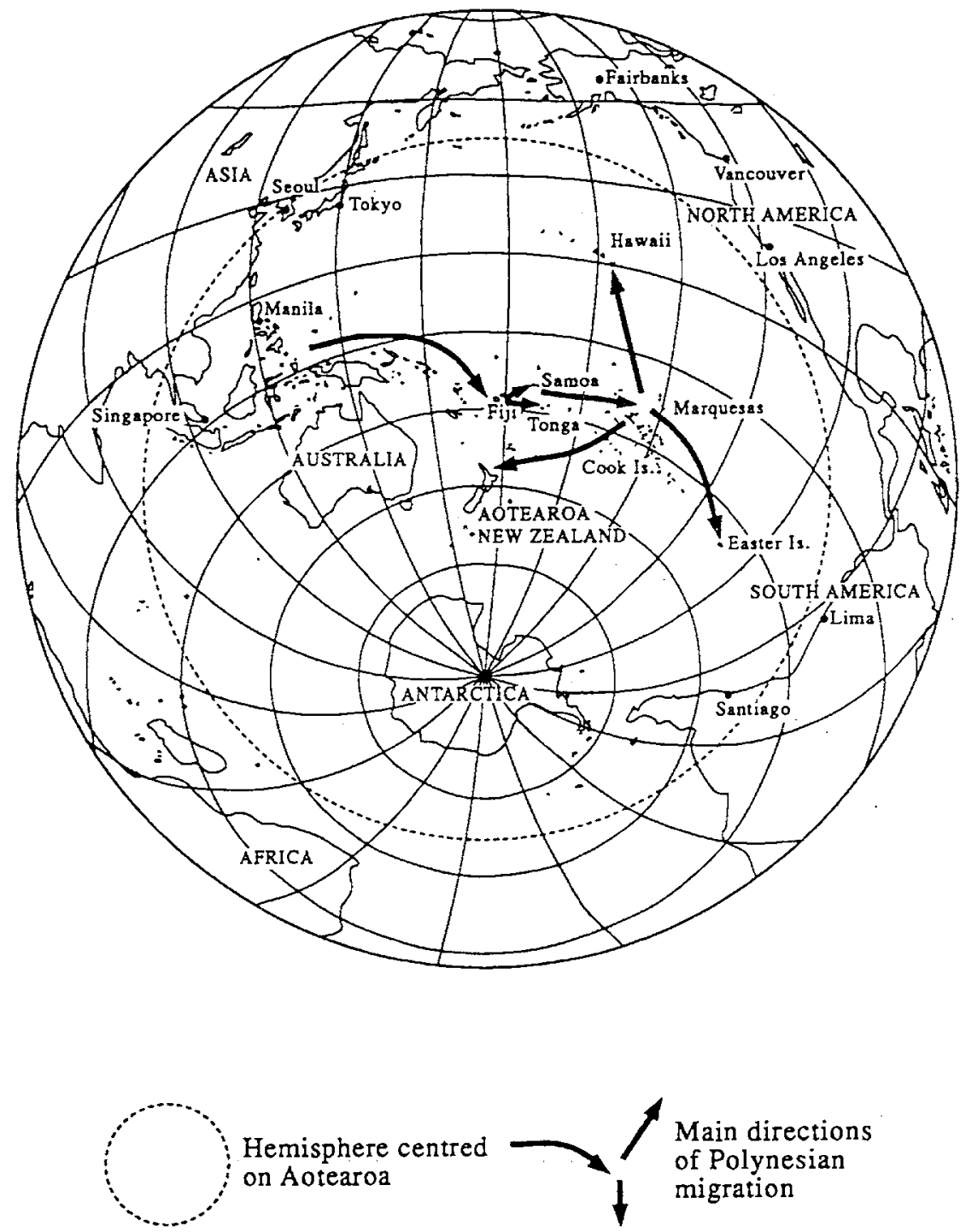

Figure 1. Aotearoa New Zealand in its Polyneslan Context 


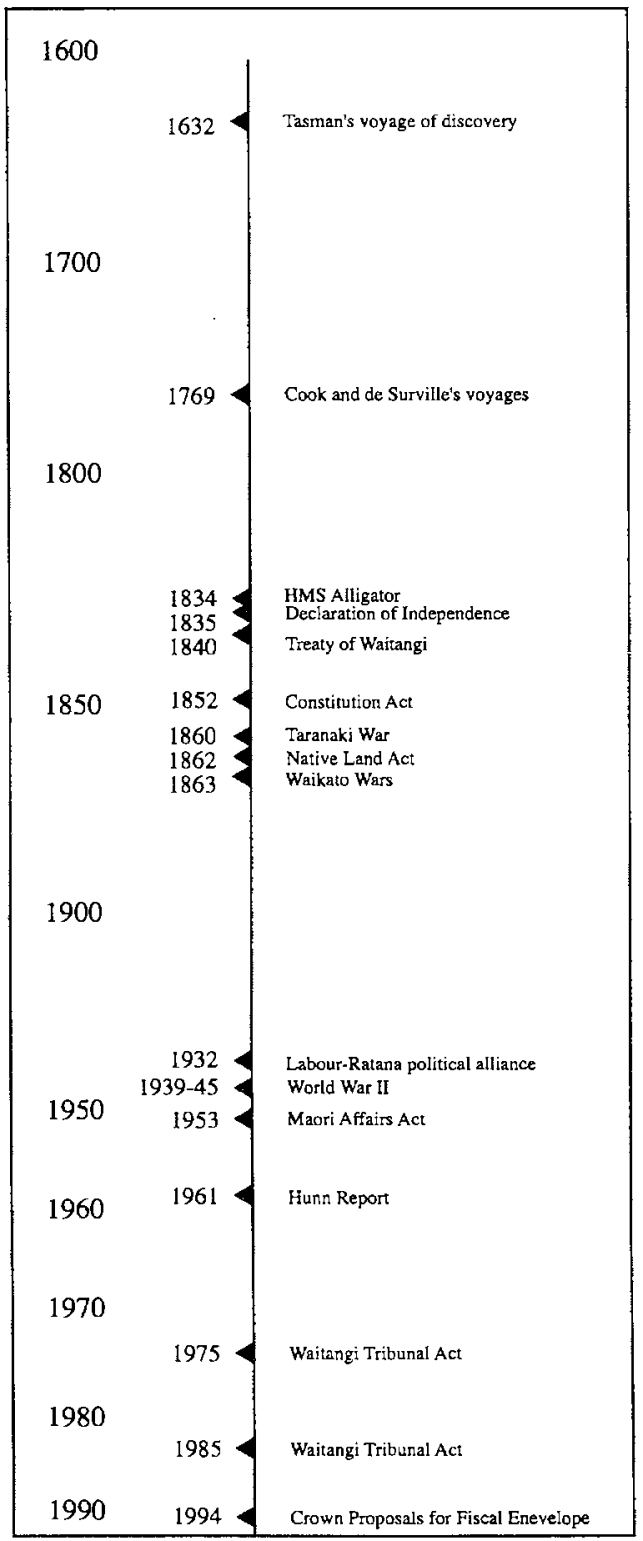

Figure 2. New Zealand: Time Line of Historical Events 


\section{ABORIGINAL HISTORY 1995 19:1}

came via the Pacific in 1769 . By the 1790 s timber and flax, seals and whales were being exploited to meet the demands of the global economy. There was a period of mutuality between host and visitors: whaling ships, sealing gangs and traders on the one hand; iwi and hapu on the other. Tribes in the northern and southern extremities of Aotearoa were willing to exchange technologies, provide shore bases and share in work and recreation in ways which respected and enhanced tribal authority (Figure 3). By the 1830 s a number of $h a p u$ and $i w i$ had incorporated commercial production into their existing social organisation: food and raw materials were being produced for Australian and global markets and some hapu were operating ships up and down the New Zealand coast and across the Tasman Sea to Sydney.

This latter enterprise triggered a significant symbolic event in 1834 and opens a window into the strength of Maori tribal structures and the colonial aspirations of the British at that date. Ships built in New Zealand carried neither register nor flag and one such, operated from the Hokianga Harbour, was impounded in Sydney. In a carefully considered move to address this situation without making moves to extend British rule to New Zealand, HMS Alligator, was sent from Sydney to the Bay of Islands. ${ }^{2}$ A meeting of 25 Northern Chiefs was convened in the presence of British and other witnesses, the nature of the problem was discussed and a solution suggested. The Captain of the Alligator provided a choice of three flags and the working of a shipping register was explained. After detailed consultation, the Chiefs agreed to the proposal and selected one of the flags which was hoisted and acknowledged by a 21 gun salute fired by the ship's crew. In this way the rangatiratanga of the tribes was affirmed and the British recognised New Zealand as a separate country. ${ }^{3}$ The symbolism of this event was incorporated into a formal document in Octoger 1835 when 33 northern rangatira published a Declaration of Independence - He Whakaputanga o Te Rangatiratanga o Nu Tirene. ${ }^{4}$

\section{0, The Treaty of Waitangi}

Between 1834 and 1840 British policy shifted from non-intervention to intervention. 5 The French in particular, but also the Americans and other European powers had an increasing presence in New Zealand waters and ports. Within Britain, the missionary and humanitarian lobbies were pushing hard for a negotiated and formalised British involvement. Even more urgent, planned colonisation was about to begin: by the end of 1839 the New Zealand Company in London and La Companie de Bordeaux et de Nantes had negotiated purchases of land and were recruiting settlers and loading ships. ${ }^{6}$ To meet these pressures and to deal with the international legal implications of the very public events of 1834 a negotiated Treaty was essential. ${ }^{7}$ Captain William Hobson, R.N. was sent to achieve this.

The English text of the Treaty was drafted by Hobson and James Busby from a brief provided by the Colonial Office. The Maori text was translated by missionaries Henry and . Edmund Williams (Appendix 1). The first gathering was at Waitangi where more than 40 chiefs and some three hundred to five hundred other members of $i$ wi and hapu were present

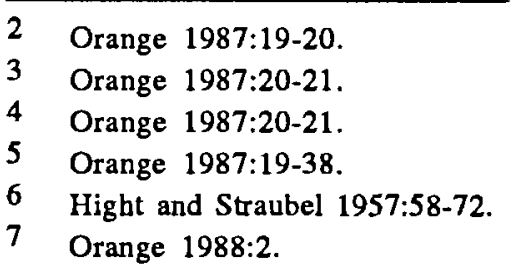


along with officials, missionaries and European onlookers. The texts were read in full in both languages and the preamble and three articles were explained and debated in Maori. The debate among the Maori continued for five hours in the presence of the Europeans, then continued on into the night after the latter withdrew. By dawn there was a consensus among the $i w i$ and hapu present that they would sign. Next day some 43 chiefs signed the Treaty on behalf of their tribes.

Copies of the Treaty were made and over the next eight months some forty similar meetings were held and more than five hundred signatures added (Figure 3). At the end of the process copies were taken back to England and published in English in the London Gazette in October 1840 so that all the world, not least the French, would be informed.

The Treaty was signed without coercion and as a result of careful discussion and debate in the Maori language. Many members of iwi and hapu were present at these discussions, and almost all of the chiefs who signed did so after careful consultation. Chiefs from a number of iwi and hapu, in particular the Arawa, Tuwharetoa and Tuhoe tribes in central North Island, refused to sign. Subsequent problems have, however, stemmed from two other factors and impacted on signatories and non signatories alike: on the one hand there are significant differences in the content of the English and Maori versions; on the other hand the implementation of the Treaty on the Crown side has devolved from London to New Zealand.

The initial outcomes were positive for both parties, more especially the British Crown and the settlers who migrated from the countries of the United Kingdom to the colonial settlements in New Zealand. Planned settlements were initiated in the 1840s and 1850s on opposite sides of Cook Strait and in the South Island (Figure 3) and there were large scale immigration and public works schemes in the 1870 s. For a time in the 1840 s and 1850 s Maori prospered as the productive economy expanded and hapu and iwi were able to compete vigorously in such commercial activities as grain production, flour milling, land transport, construction and public works. ${ }^{8} \mathrm{By}$ the end of the 1850 s the tide had turned. Legislative power and administrative decisions passed to the New Zealand House of Assembly which was dominated by merchants and settlers. The New Zealand Constitution Act, passed by the British Parliament in 1852, gave the responsibilities of government to an Assembly elected by males who held individual title to property. Iwi and hapu were thus marginalised in the political process.

\section{Loss of land, loss of memory, loss of kaitiakitanga}

The broad sweep of events between the 1850 s and the 1970 s is now being re-presented by a new generation of historians, Maori and Pakeha. ${ }^{9}$ Claudia Orange provides a number of particularly helpful overviews with differing levels of detail. 10

By the 1860 s settler pressures and Maori resistance to forced land sales built up to the point where wars broke out, initially in Taranaki, then in Waikato and Bay of Plenty. 11 The overt points of conflict were the desire of Maori Tribes to retain land for subsistence and commercial production and to exercise full tribal authority within those lands, both topics on which the Treaty is very explicit. Government provoked conflict by building roads and massing troops and then proceeded to fight the wars on a cost plus basis:

8 Temm 1990:18-23.

9 Awatere 1984; Belich 1986; Biney, Bassett and Olssen 1990; Oliver and Williams 1981; Rice 1992; Walker 1987.

10

Orange 1987-90.

11 Belich 1986. 


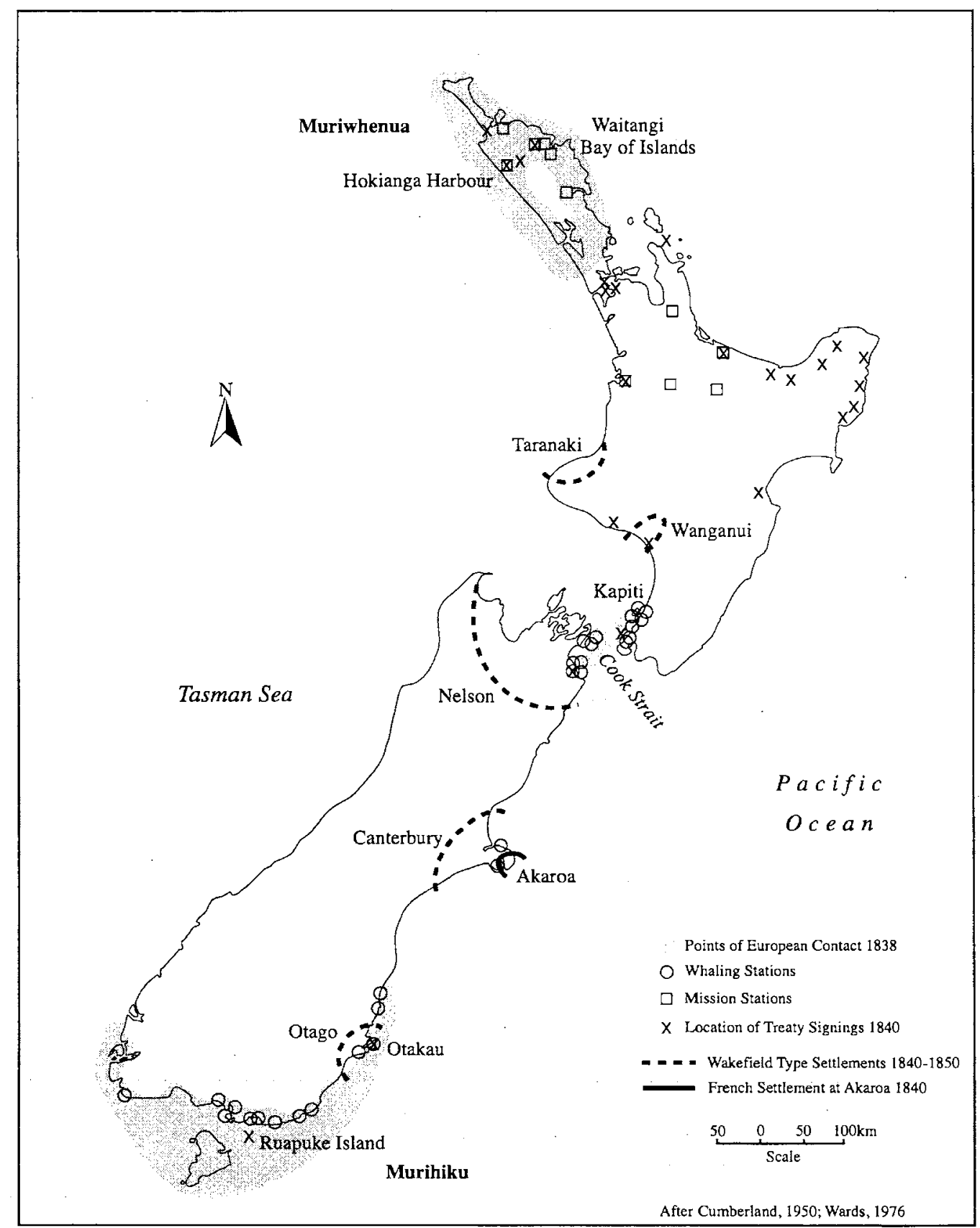

Figure 3. Aotearoa New Zealand: the context of the Treaty of Waitangi. 
whatever the scale of tribal resistance, government was able to muster sufficient troops to win each of the wars and at the end of each confiscated lands sufficient to meet their expenses in full. Each step was carefully legitimated by the House of Assembly. 12

As a result of the wars, some three million acres of land were confiscated and tribal authority was disrupted. What the settler government began by war was continued by legislation. The Native Land Court was set up in 1862 and title progressively shifted from tribes, to designated trustees, to individuals. The $i w i$ and hap $u$ who were parties to the treaty yanished as legal entitles able to own and control land. In the decades which followed, from the 1860 s to the 1960 s, some thirty million acres were lost through land sales made possible by the Native Land Court. Douglas Sinclair, writing about loss of land since the Treaty, subtitles his work "the nibble, the bite, the swallow". Wars and confiscations were the nibble; individualisation of title and the operation of the Native Land Court were the bite and the swallow. 13

Claudia Orange describes the same decades as the years of loss of memory about the Treaty. The House of Assembly in New Zealand failed to incorporate the Treaty or its provisions into domestic law or take it into account in day to day decision making. The Courts followed the same lead. By 1877 Chief Justice Prendergast declared the Treaty to be a simple nullity with no standing in domestic law ${ }^{14}$ As a result land and food gathering places were progressively removed from tribal control and government regulations intruded into all aspects of tribal life. Particularly significant was the exclusion of Maori tribes from the use and management of environmental resources. Their kaitiakitanga over land, food gathering places and water bodies was significantly diminished. The pakeha world view became dominant and Maori became marginalised in their own land. Loss of memory was, however, a pakeha phenomenon: Maori never forgot the Treaty. ${ }^{15}$

\section{The Waitangi Tribunal Established 1975}

The recovery of memory which took place in the 1970s was heralded by two events which took place in 1931 and nurtured by Maori participation in the Armed Services during World War II. In 1932 the Governor General and his wife, Lord and Lady Bledisloe, purchased the Treaty House at Waitangi and presented it as a gift to the nation ${ }^{16}$ In the same year the Labour Party and the Ratana Party, the political wing of a Maori religious movement, formed a political alliance with the Treaty of Waitangi as its comerstone. They were successful in the 1935 election and Labour moved quickly to implement social welfare and employment policies which were beneficial to Maori as well as European. More fundamental Treaty issues were not addressed for four more decades by which time pakeha awareness had changed and the Treaty House at Waitangi had become a focal point for protests and land marches.

The legislation to set up the Treaty of Waitangi Tribunal was passed by the KirkRowling Labour Government in October 1975 after extended Committee hearings (Figure 2). Keith Sorrenson (1967), Paul Temm (1990), Bill Oliver (1991) and Evelyn Stokes (1992) provide interesting windows into the manner in which its operation and style of

14 Orange 1987:186-7.

15 Awatere 1975:56-74; Walker 1990:160-185; Orange 1987:185-225.

16 Cant 1992; Orange,1987:234. 
working have evolved. ${ }^{17}$ The Tribunal is empowered to hear claims by Maori, individually and collectively, that acts or omissions by the Crown have deprived them of their rights under the Treaty. As initially set up these powers were not retrospective: the Tribunal could investigate actions or policies from 1975 onwards; actions of the Crown between 1840 and the passing of the 1975 Act were outside its terms of reference.

The work of the Tribunal began slowly. It was initially made up of three members of whom only one, Graham Latimer, the nominee of the Minister of Maori Affairs, was Maori (Figure 4a). Its style of working was formal, its rituals were those of the Law Courts and it met in buildings unfamiliar to most claimants. Few claims were lodged in the 1970 s and the Tribunal was slow to address significant issues. As Oliver comments, 'it was not expected to hear many claims, to meet often or to cost much'18

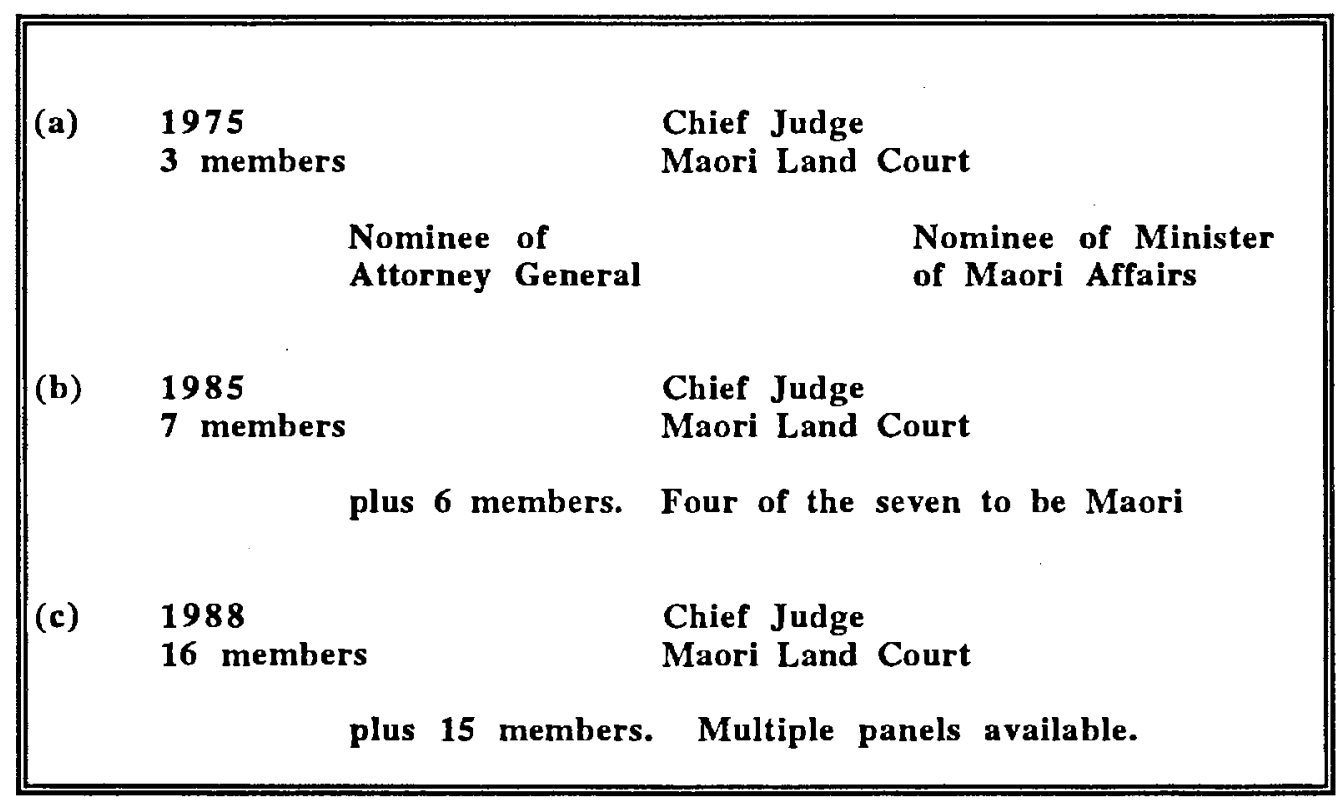

Figure 4. Membershlp of the Treaty of Waltangi Tribunal, 1975-1993.

The claim by Joseph Hawke and other members of Ngati Whatua lodged in October, 1976 provides an example. The claimants had collected shellfish from a traditional area for a gathering to be hosted at Te Ongawhatu Marae and were apprehended and charged under the Fisheries Regulations (1950). The hearing by the Waitangi Tribunal took place on May 30 and June 1, 1977 and the Tribunal reported in March 1978. It declined to make any recommendation on the grounds that the claimants had not been prejudicially affected since the Magistrate's Court had chosen to enter no conviction ${ }^{19}$ The larger issues were not

17 Sorrenson 1967; Temm 1990; Oliver 1991; Stokes 1992.

18 Oliver 1991:10.

19 Waitangi Tribunal 1978; Temm 1990:6; Oliver 1991:82-83. 


\section{RECLAIMING LAND: THE WAITANGI TRIBUNAL}

considered by the Tribunal and were subsequently addressed by the High Court in 1986 when Tom Te Weehi appealed against a prosecution for similar actions in North Canterbury ${ }^{20}$

It is not surprising that the work of the Tribunal languished between 1975 and 1981: Maori people had no great confidence in its style of working; most of their concerns were out of bounds since they related to events prior to 1975; issues of importance for claimants were not directly addressed by the Tribunal.

\section{The Tribunal Expands 1985-1988}

Changes took place from 1981 onwards. Judge Gillanders Scott retired and Judge Edward Durie, of Rangitane and Ngati Kauwhata lineage, replaced him as Chief Judge of the Maori Land Court and Chairman of the Waitangi Tribunal. Shortly after the Attorney General nominated Paul Temm to join Durie and Latimer. Under Durie's leadership these three worked together to change the style and accessibility of the Tribunal ${ }^{21}$ Hearings were now held on tribal marae as well as other public buildings, and when hearings were on a particular marae the protocol of that marae was followed. Claimants and witnesses were allowed to address the Tribunal in either Maori or English and translation was provided at the conclusion of each address. Ways of working used on the marae have now flowed over into hearings in other places: all parties concerned, tribunal, claimants, Crown representatives, other interested parties and members of the public share the same food in the same dining area during meal breaks. New procedures have been developed to ensure that equivalent standards of evidence are maintained in situations where cross examination is culturally inappropriate.

The new procedures were initiated in 1982 when the Tribunal met on Manukorihi Marae at Waitara in Taranaki to hear a claim brought by Te Ati Awa for protection of their fishing reefs and restoration of kaitiakitanga in the face of urban industrial pollution (Figures 5 and 6). They were significantly reinforced in 1984 when Ngati Pikiao, the kaitiaki of the Kaituna River, and Northern Tainui, kaitiaki of the Manukau Harbour adjacent to urban Auckland, brought their claims ${ }^{22}$ As the new procedures were put in place confidence in the integrity of the Tribunal rose and the number of claims lodged increased. In the wider political arena protests and pressures for change had escalated further and the Lange-Palmer Labour Government, elected in 1984, passed a further Waitangi Tribunal Act in 1985. This act extended the powers of the tribunal to hear grievances dating back to 1840 and enlarged its membership from three to seven, four of whom would be Maori (Figure 4b). Some claims were resubmitted and a number of more complex claims, including the Ngai Tahu claim were lodged. By 1987 there were more than eighty claims awaiting settlement and Government recognised the need to provide multiple panels and parallel hearings. Since 1988 there have been sixteen tribunal members (Figure 4c). By that date the Tribunal had demonstrated a very effective bicultural style of working and the requirement for a Maori majority was deleted.

The sequence of claims heard between 1975 and 1993 is shown in Figure 5. Oliver groups them into three main clusters: reclaiming the waters; reclaiming the land; reclaiming the language 23 A number of claims incorporate two or three of these

20 Te Weehi $v$ Regional Fisheries Officer 1986. Compare Regina $v$ White and Bob 1964; Sparrow v Regina 1986.

21 Temm 1990:6-12; Sorenson 1987:176; Oliver 1991:10-17.

22 Waitangi Tribunal 1983, 1984, 1985.

23 Oliver 1991. 


\section{ABORIGINAL HISTORY 1995 19:1}

components and there are, in addition, significant claims which focus on fisheries and minerals. Underneath all the claims is a reassertion of Maori values: mana is to be affirmed and kaitiakitanga is to be recovered. In the sections which follow I explore selected examples which provide a basis for further comments on the significance and style of working of the Tribunal. The first set of examples are selected from the water related claims grouped together by Oliver. The second is the Ngai Tahu claim with a multiplicity of separate components.

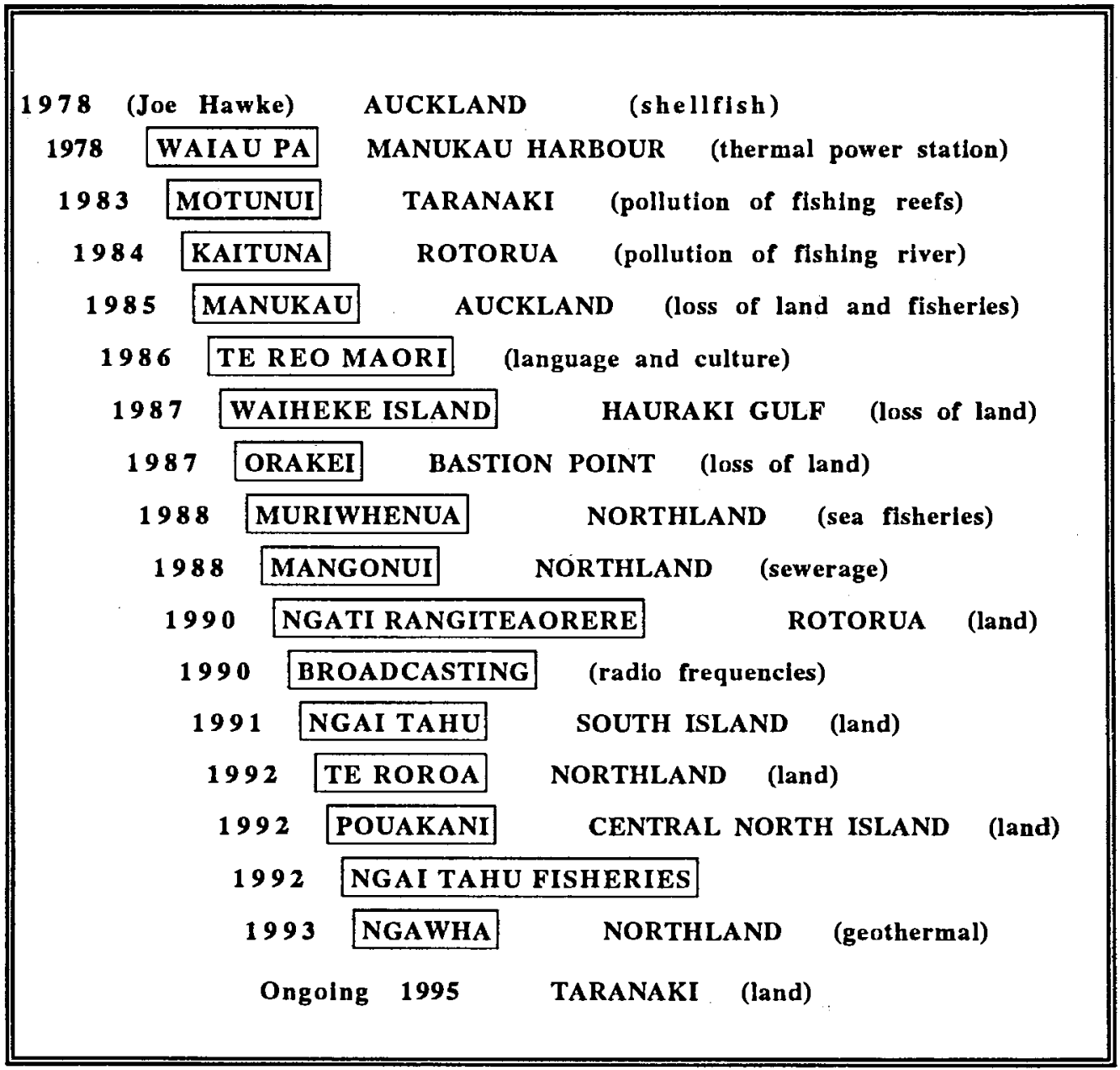

Figure 5. Claims heard by the Waitangi Tribunal 1975-1995.

'Reclaiming the Waters' .

(a) Waiau Pa

The Waiau Pa claim which opens the suite of water related claims may seem inconsequential. It did little to raise the profile of the Tribunal or establish its credibility 
$\underline{\text { Key }}$

\section{Location Specific Claims}

Muriwhenua Fisheries

Taranaki Land Claim

Ngai Tahu Claim

Non land or sea based claims: Te Reo Maori Radio Frequencies

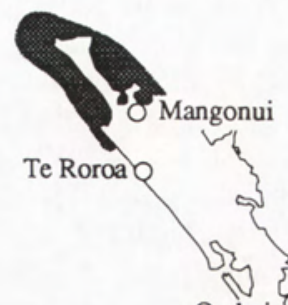

Manukau Harbour

rakei OWaiheke Island

Waiau Pa

Welcome BayO' Kaituna River Ngati RangiteaorereO
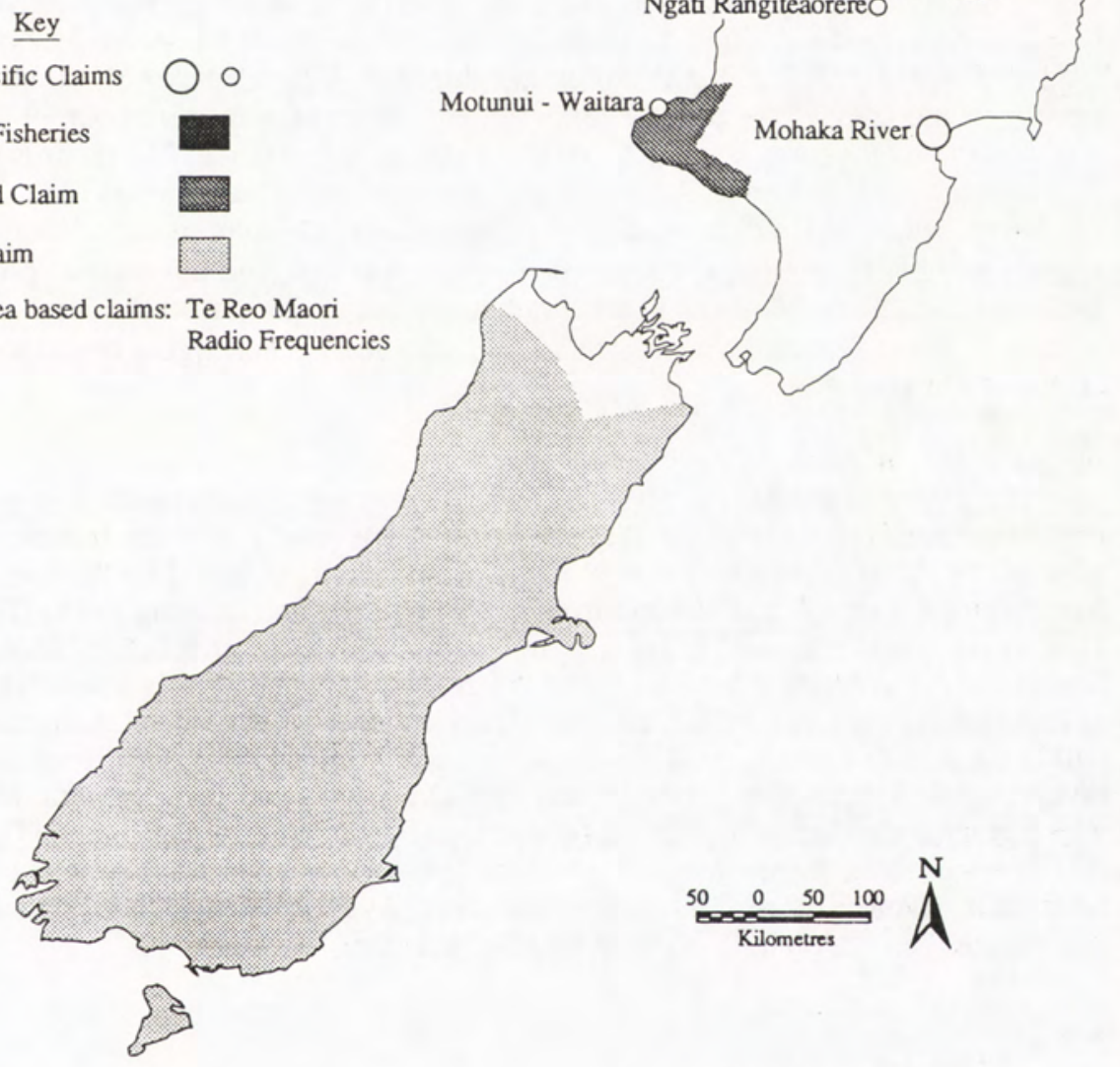

after Stokes, 1992 ; Oliver, 1991

Figure 6. Location of Claims to the Waitangi Tribunal 1975-1993 
among Maori people. The claim was triggered by the New Zealand Electricity Department when it initiated proposals to build a Thermal ElectricPower Station near Waiau Pa on the shores of the Manukau Harbour. The Power Station would be close to the Maori settlement and some 560 hectares of tidal mudflat would be used for cooling ponds.

Ted Kirkwood and the Waikato subtribes living adjacent to the Manukau filed claims in 1977. Hearings were held in the Intercontinental Hotel in Auckland in front of the tribunal of three. Evidence presented by the claimants focused on the deterioration of the aquatic environment and the impact which this would have on shellfish, on food chains and on the pelagic fish in the Manukau Harbour. While the evidence was being considered the Regional Water Authority indicated that it would not approve a water right for the cooling ponds. New Zealand Electricity Department, weighing up the options, decided to abandon the proposal before the Waitangi Tribunal published its findings in February, 1978. ${ }^{24}$

The Tribunal Report contained no recommendations and generated little media interest. Its findings however, were significant: the grievances of the claimants were upheld; the fisheries resource would be seriously diminished by cooling ponds if the proposal proceeded. ${ }^{25}$ Equally important was the level of political skill and awareness generated among the Northern Tainui people who participated in the hearings. Ranginui Walker notes how Ted Kirkwood identified the ongoing nature of the conflict between Maori values and industrial development and shared his insights with Mrs Nganeko Minhinnick, soon to emerge as 'the voice of the kaitiaki', the guardians of the Manukau Harbour. ${ }^{26}$

Walker uncovers a second link of long term importance. He records that David Williams, Lecturer in Law at Auckland University, attended the hearings in the ballroom of the Intercontinental Hotel in Auckland. This incongruent cultural experience triggered a version of how things could be, freed from court rituals and adversarial procedures. 27 Williams formalised his ideas in a memorandum which he sent to the Minister of Maori Affairs. ${ }^{28}$ What Williams visioned in 1977 , Durie and his colleagues began to implement at Waitara in 1982.

\section{(b) Motunui - Waitara}

Aila Taylor of the Ati Awa tribe in Taranaki was not daunted by the low profile or the limited terms of reference of the Tribunal in 1981. His people were the kaitiaki of the reefs adjacent to the Waitara River mouth which were heavily polluted by domestic sewerage from Waitara Borough and effluent from a meat packing and freezing works (Figure 7). In 1980 Government proposed to build a large petrochemical plant at nearby Motunui. In the face of Ati Awa objections, the Regional Water Board granted Syngas a permit to discharge effluent into the sea east of Waitara. Aila Taylor and Ati Awa lodged their claim in 1981 within the terms of reference of the 1975 Waitangi Tribunal Act. The Crown had a double involvement: Syngas was partly owned by Government and the Regional Water Board which granted the discharge right was constituted by Government legislation. The proposed outfall would pollute their remaining fishing reefs. Three significant strands of grievance were interwoven: loss of food gathering rights; physical and spiritual contamination of water bodies; exclusion from decision-making processes.

\footnotetext{
24 Waitangi Tribunal 1978.

25 Waitangi Trubunal 1978:6-19.

26 Walker 1990:250-51.

27 cf. Berger 1977.

28 Walker 1990:245.
} 


\section{RECLAIMING LAND: THE WAITANGI TRIBUNAL}

The Tribunal sat at the Manukorihi Marae in 1982 and heard evidence from Ati Awa kaumatua, from scientists, planners and other interested parties, including Syngas and environmental groups. ${ }^{29}$ Equal attention was given to scientific evidence and traditional knowledge. In their findings the tribunal decided that both texts of the Treaty provided solid support for the claimants: the English version was very specific about fisheries while the Maori version made a very explicit link between tino rangatiratanga, the exercise of tribal control, and taonga which included food gathering places. The Motunui reefs were places where the kaitiakitanga of Ati Awa should berecognised but the processes of legislation and local authority decision making had failed to recognise this. The water pollution which resulted was spiritually and culturally offensive as well as physically hazardous. The planning and decision-making process controlled by Government through the Regional Water Board was largely to blame.

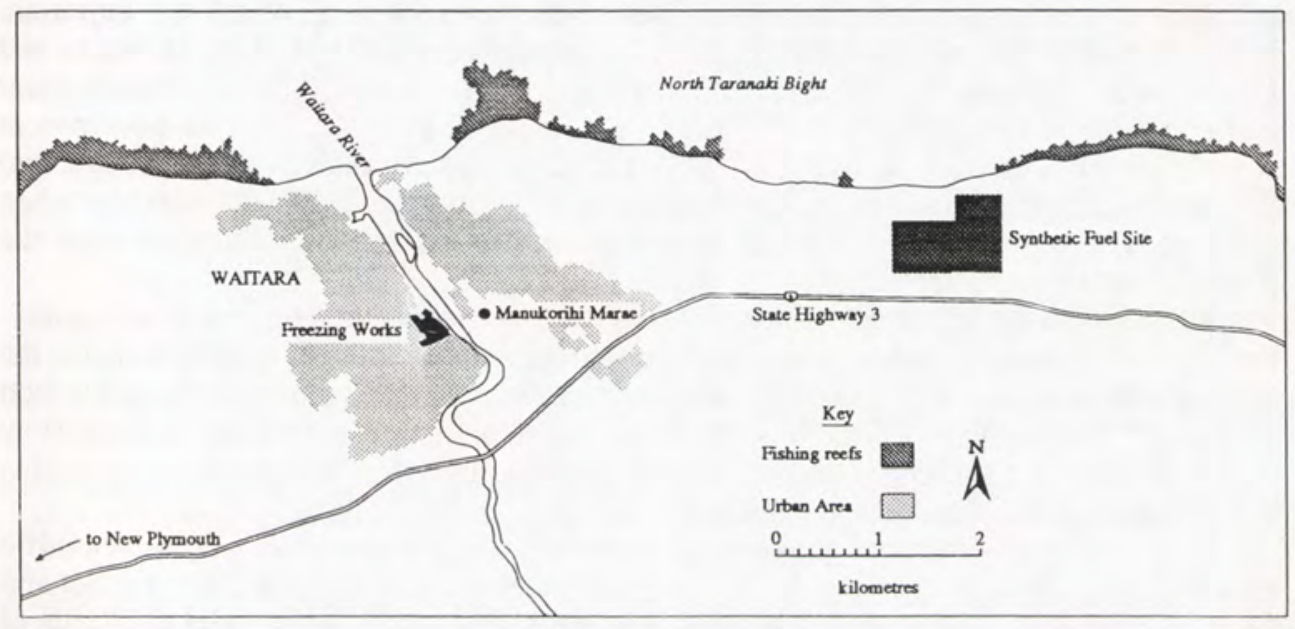

Figure 7. The Motunui-Waitara Claim

The Motunui-Waitara Report is a short but substantial document. ${ }^{30}$ The Tribunal firmly took the legal and moral high ground and balanced this with pragmatic recommendations designed to avoid any sort of winners and losers confrontation. In the local context they recommended that the Syngas plant be allowed to proceed without the discharge into the sea. In the short term the effluent could be channelled into the Waitara Borough Scheme, while a long term solution was worked out. Syngas, Waitara Borough and Ati Awa would work together to find an answer and create a better environment for all to enjoy. Kaitiakitanga would be restored by involving the local $i w i$ in the search for pragmatic local solutions.

At the national level the Report pointed out deficiencies in fisheries and planning legislation and recommended that the appropriate Government Ministers move to address these. The scale and substance of the Motunui report took the Government of the day by

29 Waitangi Tribunal 1983.

30 Waitangi Tribunal 1983. 
surprise. The immediate reaction of Prime Minister Muldoon was to reject both the findings and the recommendations and affirm the priority of large scale energy developments over Maori and environmental concerns. Green issues were firmly on the national agenda and media opinion had moved decisively. There was widespread and sustained support for the Tribunal and the environmental and cultural issues addressed in its report. Muldoon recognised that he had misread public opinion and backed down. His Ministers began to implement the recommendations.

\section{(c) Kaituna River}

In July 1984 the Waitangi Tribunal made up of Durie, Latimer and Temm was convened at Te Takinga Marae, near Rotorua, to hear a claim brought by Sir Charles Bennett and other kaumatua of Ngati Pikiao. They were the guardians of the Kaituna River, its waters and its riverbank resources which provided food, recreation and plants for handicrafts. Again the focus was on water quality: Rotorua City had an effluent disposal problem : sewerage had been flushed into Lake Rotorua to the point where this important national amenity became eutrophic (Figure 8). The engineers in the Ministry of Works and Development decided that the best solution was to bypass the lake, build a treatment plant and pump the effluent from that into the Kaituna River. Offered a $\$ 7$ to $\$ 1$ government subsidy on the total cost, Rotorua City was strongly attracted to the Ministry scheme and supported an application to the Regional Water Board. Ngati Pikiao objected when discharge rights were applied for and lodged a claim to the Waitangi Tribunal when the discharge rights were granted.

The Kaituna Claim raised similar issues to the Motunui Claim. Not just water quality, medical hazards and the loss of a significant economic and recreational amenity but also the spiritual contamination which occurs when body wastes are mixed with waters used for food gathering ${ }^{31}$ Related to this is the loss of tino rangatiratanga as tribal control is usurped by the Regional Water Board and exclusion from kaitiakitanga when the guardians are unable to exercise their traditional responsibilities.

In its report the Tribunal gave substantial weight to traditional as well as scientific evidence, spent time unravelling the bureaucratic processes which created the conflict and directed attention to alternative methods of waste disposal which might meet the needs of the city and protect the rights of the Maori claimants. The legal and historical basis for their finding was clearly set out and two main strands of recommendation made. Rotorua District Council should be allowed to investigate a land based solution to the effluent problem whereby the organic residues would be sprayed onto a large area of exotic pine forest. The Minister of Works and Development was asked to review the Water and Soil Conservation Act in order to incorporate Maori spiritual and cultural values into the process of hearing and granting water rights (Appendix 2).

The pragmatic local recommendation produced a winner and winner situation. Ngati Pikiao took up the initiative and pointed the attention of the Rotorua District Council to a number of viable alternatives, all land based ${ }^{32}$ The Ministry of Works and Development agreed to redirect its subsidy. By May 1991 the District had an operating scheme which is economically and environmentally superior to the initial proposal..$^{33}$

At the national scale the Government had changed. Geoffrey Palmer, incoming Minister of Works and Development and Attorney General for the new Labour Government,

31 Waitangi Tribunal 1984:7-11.

32 Parliamentary Commissioner for the Environment 1988:53-54.

33 Oliver 1991:96. 


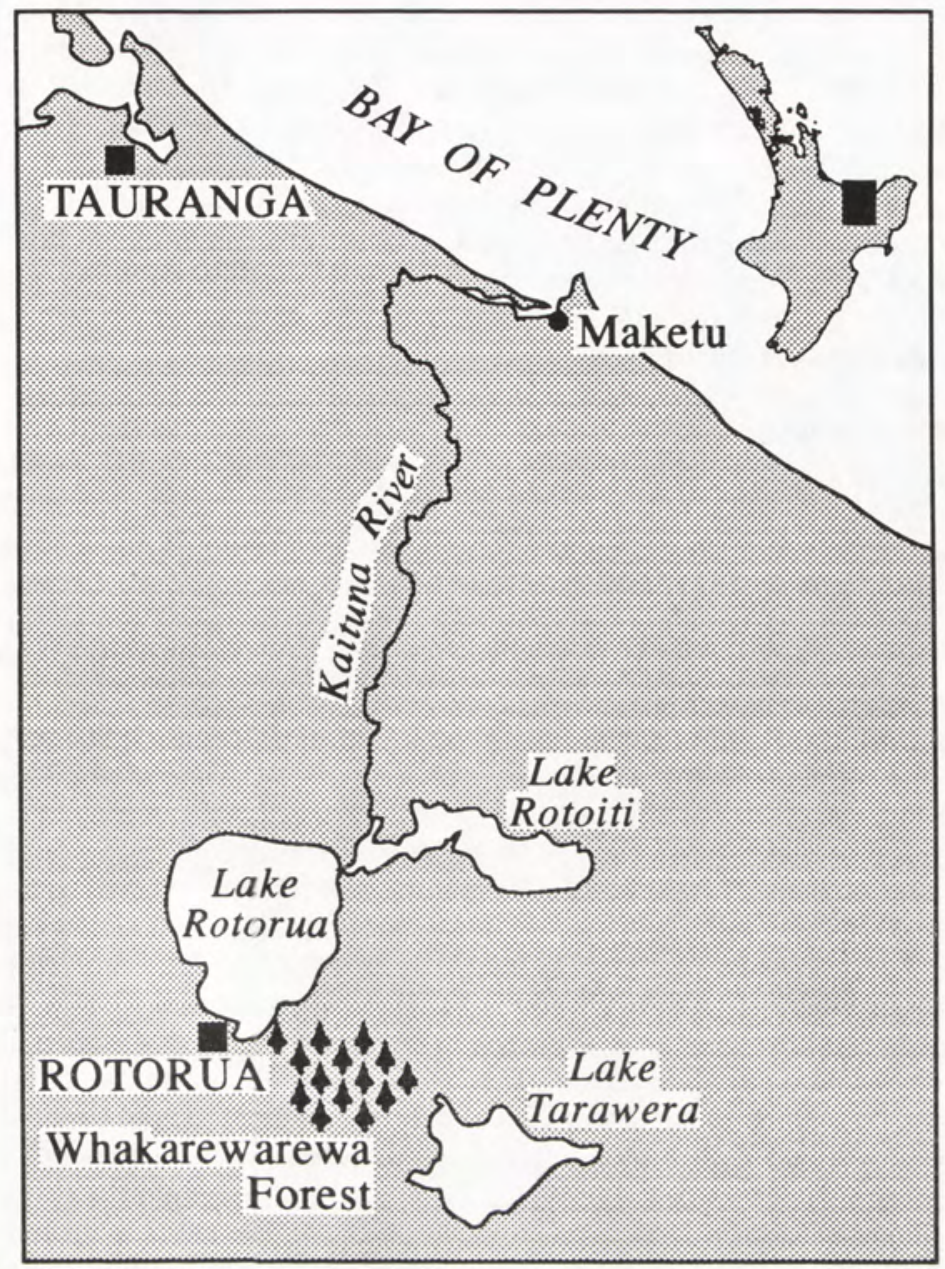

Figure 8: The Kaituna River Claim

took up the challenge posed by the Waitangi Tribunal. An extensive process of Resource Management Law Reform was initiated in 1984. The recommendations of the Tribunal and the personal insights of claimants such as Aila Taylor and Nganeko Minhinnick became a significant part of that process.

The Motunui and Kaituna reports together provide windows into the style of working which the Waitangi Tribunal evolved in the first half of the 1980s. The mana of the Tribunal was quietly established and expanded with each successive week of hearing as claimants, Crown, expert witnesses and other interested parties made their inputs. The implications of the Tribunal's mandate and the interplay between the English and Maori texts of the Treaty were progressively explored in the context of particular claims and reported in successive findings. 
What the Motunui and Kaituna claims began, the more complex Manukau Claim, lodged by Nganeko Minhinnick and her fellow kaitiaki in 1983, continued. ${ }^{34}$ The combination of water related claims and the limitation in terms of reference to contemporary actions of Government gave a creative focus to the work of the Tribunal at this early stage. In this situation the relationship between the Treaty and current legislation came under close scrutiny. The Tribunal was low key and pragmatic in the manner in which it addressed specific local problems. By avoiding major confrontations at this level it was able to have a significant impact on medium term issues such as planning and environmental law and raise significant questions as to ways in which hapu and iwi can participate in local and regional government.

\section{The Ngai Tahu Claim}

The Ngai Tahu Claim is significant in its own right and, in addition, provides insights into a style of working which characterises the Waitangi Tribunal in its second decade of operation. The Ngai Tahu Claim is wide-ranging and extensive. It has a strong focus on land and involves grievances dating back to 1844 and voiced to the Crown from 1848 onwards. A common strand running through all the components of the claim is the very intense relationships between Ngai Tahu, their lands and food gathering places, and their role as kaitiaki or guardians of land and resources. 35

Ngai Tahu are the kaitiaki for an area which embraces some eighty per cent of the South Island, more than half of the land area of New Zealand. Their claim, lodged in 1986 with the new legislation in position, was heard by a panel of seven members chaired by Deputy Chief Judge Ashley McHugh. The hearings extended over 27 months between August 1987 and October 1989. The typical pattern was for the Tribunal to hear evidence for one week each month with the intervening weeks being made available to all parties for preparation and scrutiny of material presented. The style of hearing followed that evolved under the chairmanship of Chief Judge Edward Durie: when the claimants were presenting detailed evidence hearings were held on marae in the various parts of the Ngai Tahu domain or rohe (Figure 9). When the Crown and other parties were presenting material the venues selected matched the ethos of the groups involved, for example school or university halls, conference rooms attached to motor hotels or commercial associations and community buildings such as a rugby club hall. ${ }^{36}$ The Tribunal also developed a system whereby written commentaries could be lodged and answered as an alternative to cross examination of evidence. This ensured that evidence came under appropriate scrutiny and examination without introducing an adversarial component into the proceedings. ${ }^{37}$

34 Waitangi Tribunal 1985; Walker 1990:250-253; Oliver 1991:23-27. 


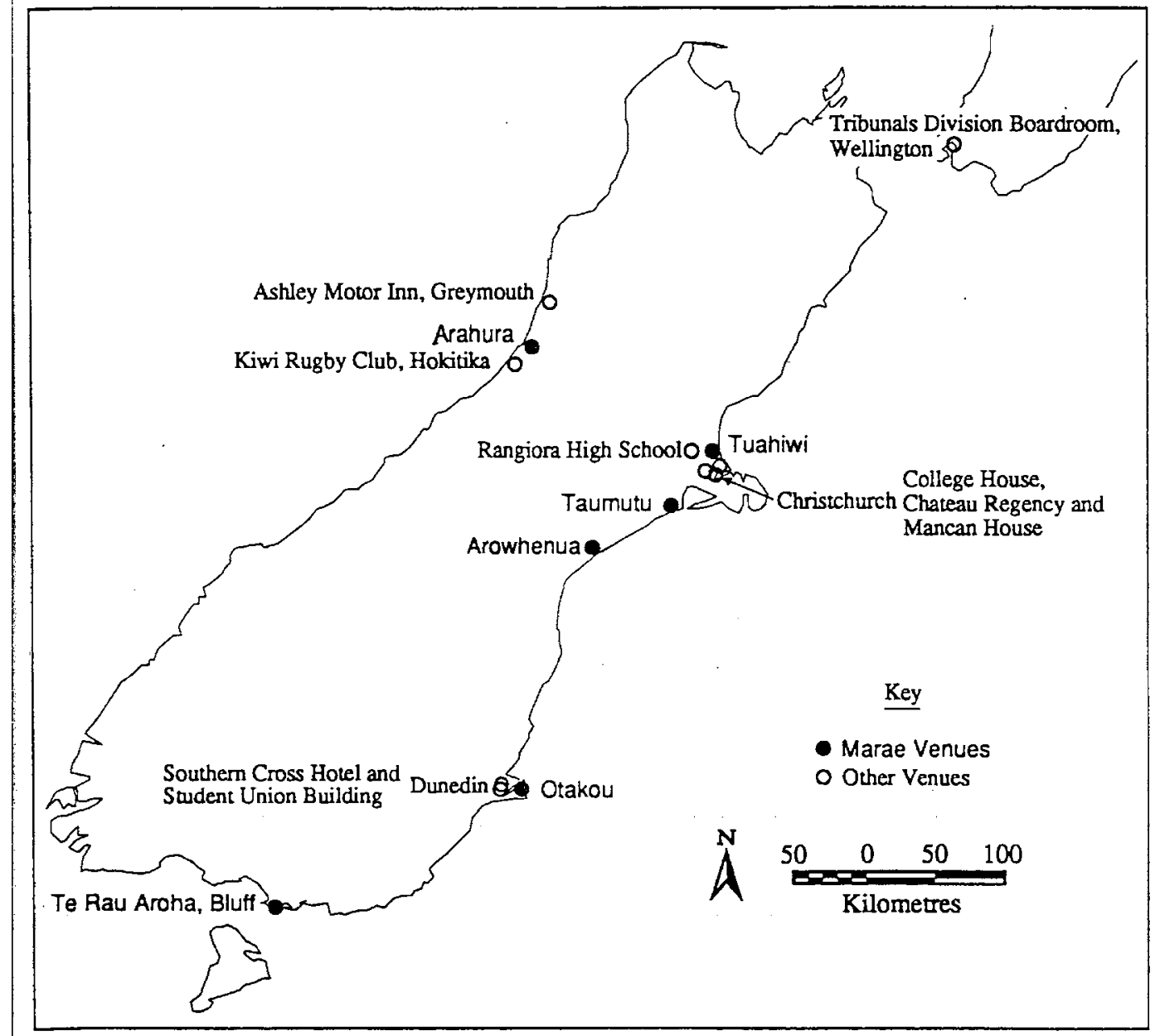

Figure 9. The Ngal Tahu Clalm: Venues for Public Hearings 1987-1989 


\section{'The Nine Tall Trees'}

The claim involved sets of grievances relating to a sequence of eight land purchases made by agents of the Crown between 1844 and 1864 (Figure 10). There were, in addition, a set of grievances relating to the loss of food gathering places, mahinga kai, in all eight areas. As the hearings progressed and the Tribunal visited the marae shown in Figure 9, local grievances were presented by claimants and received by the Tribunal as additions to the main claim. By October 1989 some 108 ancillary claims had been added. Mr Paul Temm, now Counsel for Ngai Tahu, used strongly visual imagery to embrace and organise all of this diverse material. The nine geographic components were described as the nine tall trees; the 73 separate grievances associated with these trees were identified as the branches while the multiplicity of ancillary claims became the undergrowth. The Tribunal accepted this imagery and used it to good advantage in the months that followed.

A number of grievances were common to eight of the tall trees: there were concerns about the manner in which each purchase was negotiated and there were concerns that the reserves which were eventually designated were too small to provide an adequate economic base for present and future generations and too few to protect the mahinga kai, the food gathering places and their resources in rivers, lakes, lagoons, forests and wetlands. This latter concern is repeated when the ninth tall tree is addressed under the heading of mahinga kai.

There were some specific concerns associated with particular claims. Pounamu, a form of greenstone or jade, found especially in the Arahura River valley on the West Coast, was a taonga or treasure of special importance for all Maori. Poutini Ngai Tahu were adamant that they had not sold it along with the land and were aggrieved when inadequate reserves were designated to protect it. Poutini Ngai Tahu were also aggrieved when their reserves, including a 500 acre block of urban land in Greymouth, were taken out of their effective control by Acts of Parliament and converted into perpetual leasehold with fixed rentals and automatic right of renewal. ${ }^{38}$

In three instances there were claims that substantial areas of land had not been covered in any of the purchases. The largest of these, described as 'the hole in the middle' referred to the area of the Kemp Purchase between the foothills and the main divide (Figure 10). This includes land occupied by pastoral sheep runs held on licence from the Crown, a number of large mountain lakes used for hydro-electric power generation, and high mountains which play a significant role in the Aoraki Creation legend. In the southwest the area known to other New Zealanders as Fjordland similarly plays an important role in the Rakaihautu Creation legend. Large parts of both these areas are now included in National Parks. Closer to urban Christchurch there are important areas in and adjacent to Banks Peninsula, which were left out of the Kemp Purchase while the situation of the French at Akaroa was clarified. Some but not all of these latter areas were included in the Port Levy, Port Cooper and Akaroa purchases.

38 Waitangi Tribunal 1991:121-142. 


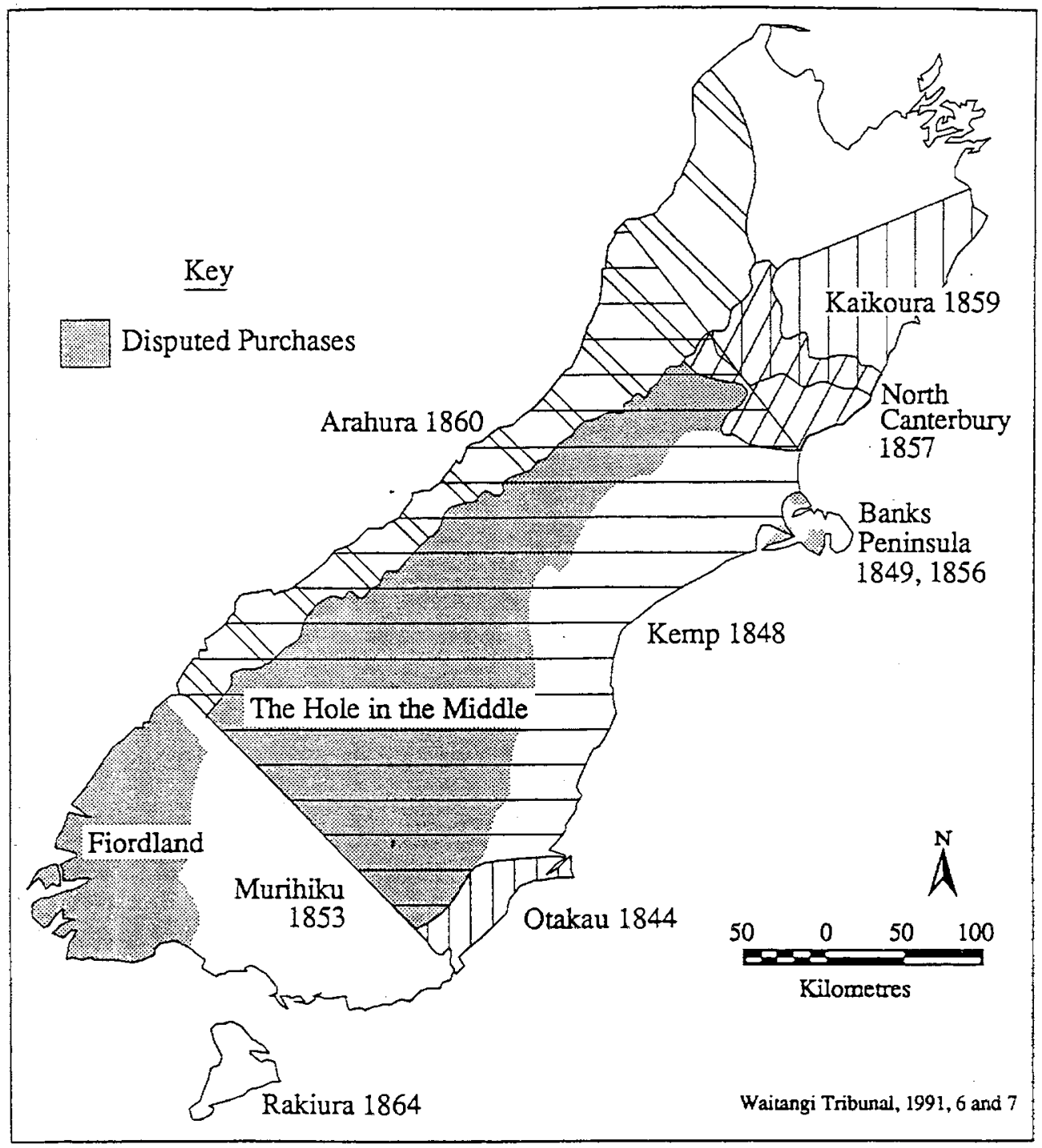

Figure 10. The Nine Tall Trees of the Ngai Tahu Claim: the land purchases and the areas whlch the Claimants maintained were not Included. 


\section{The Ngai Tahu Reports}

The findings of the Waitangi Tribunal on the Ngai Tahu claim have been separated into three reports. In November, 1988, well into the second year of hearings, the Tribunal was aware that its recommendations on sea fisheries contained in the Muriwhenua Fishing Report, 1988 (Figure 6) were the subject of actions in the High Court and the Court of Appeal. ${ }^{39}$ Aware of specific issues of propriety and wider questions of cost and convenience, the Waitangi Tribunal considered suspending its work on sea fisheries and discussed this possibility with the claimants, the Crown and other parties including the Fishing Industry. 40 The consensus then was to continue hearings and include sea fisheries in the main report. By May 1990 circumstances had changed and certain High Court proceedings were adjourned: at that point the Fishing Industry sought permission for additional evidence, prepared for the High Court, to be presented to the Waitangi Tribunal. The other parties agreed and the Ngai Tahu Sea Fisheries hearings were resumed in June and September $1991 .^{41}$ In this manner the sea fisheries component became separated from the remainder of the Ngai Tahu Report.

The first of the Ngai Tahu Reports, presented to the Minister of Maori Affairs in February 1991, deals with the 'nine tall trees' and 73 related grievances. It is published in three volumes and runs to 1254 pages. The second report, entitled Ngai Tahu Sea Fisheries Report, was presented in 1992 and is 407 pages long. 42 A third report dealing with the 'undergrowth' was presented in 1995 when investigation of these ancillary claims was completed. ${ }^{43}$ After 145 years of grievance the mana of Ngai Tahu and the Crown has been affirmed: the evidence has been presented in full and assessed by the Tribunal. The stage is set for Ngai Tahu and the Crown to negotiate a settlement. The process which has been set in motion by the 1991 report provides the opportunity for a new and significant relationship between Ngai Tahu and the Crown and an important window into the present role and style of working of the Waitangi Tribunal.

\section{Style of Working II}

In the 1980s, as evidenced by the Motunui and Kaituna Reports discussed above, the Waitangi Tribunal made detailed recommendations to Government. Some of these recommendations addressed immediate local problems and suggested remedies; other recommendations were directed to the wider responsibilities of Government in the legislative, planning and resource management fields. By the time the first Ngai Tahu Report was completed in 1991 the style of working had changed. Tribunal, Crown and claimants had each played their part in moving towards a new way of identifying and implementing remedies.

The Ngai Tahu Report, 1991 is designed to provide a common baseline for face to face negotiations between tribe and government. Recommendations are minimal and are directed to a small proportion of the grievances upheld: some are directed to aspects of the claim where immediate action is needed, for example the ownership of pounamu; some are directed to areas where legislation is needed to embrace concerns common to a number of tribes, for example the perpetual leases of Maori Reserve Land; some are directed to the

\footnotetext{
39 Waitangi Tribunal 1988; Renwick 1990:62-73.

40 Waitangi Tribunal 1991:26.

41 Waitangi Tribunal 1992a:6-8.

42 Waitangi Tribunal 1992a.

43 Waitangi Tribunal 1995.
} 


\section{RECLAIMING LAND: THE WATTANGI TRIBUNAL}

protection and joint management of important mahinga kai resources such as Wairewa (Lake Ellesmere). There are, in addition, recommendations designed to reimburse Ngai Tahu for some of the costs involved in presenting the claim and a recommendation that the Crown grant the sum of $\$ 1$ million to enable the Ngai Tahu Trust Board to fund its negotiations for a settlement. 44

\section{The Baseline for Remedies}

The larger efforts of the Waitangi Tribunal have been directed to establishing the factual baseline and providing an appropriate moral climate for negotiations on remedies. The factual baseline is provided in the 25 chapter report which summarises the evidence and explores the balance of probabilities for contentious issues such as 'the hole in the middle' (Figure 10). Each of the 73 grievances is carefully assessed: some, such as the Crown's failure to set aside adequate reserves for present and future generations of Ngai Tahu, were conceded by Crown, counsel and researchers during the hearings; of the others some are sustained and some are not sustained. The 'hole in the middle' and the exclusion of Fjordland from the Murihiku purchase of 1853 are not sustained. The non purchase of 28,000 acres of Banks Peninsula and the non purchase of the pounamu resources of Poutini Ngai Tahu are sustained.

The most substantial areas where grievances are upheld and where remedies must be negotiated relate to reserves. The Crown purchased more than 34 million acres of land for less than $\$ 30,000$. In the words of the preface to the report:-

This claim is not primarily about the inadequacy of price that Ngai Tahu was paid .... .... Ngai Tahu had certainly a sense of grievance about the paucity of payment they received for their land but then Ngai Tahu have always regarded the purchase price not as a properly assessed market value consideration in the European concept but rather as a deposit; a token, a gratuity. Ngai Tahu understanding and the substance of their expectations was that they agreed to share their resources with the settler. Each would learn from the other. There was an expectation that Ngai Tahu would participate in and enjoy the benefits that would flow from the settlement of their land. As part of that expectation they wished to retain sufficient land to protect their food resources. They expected to be provided with, or to have excluded from the sale, adequate endowments that would enable them to engage in the new developing pastoral and commercial economy. 45

The reserves set aside did not permit this. On the balance of evidence presented to it, the Tribunal estimates that there were 3,000 Ngai Tahu living in the 1840s in which case they received less than 13 acres each. ${ }^{46}$ The Crown had failed to meet its Treaty obligations and Ngai Tahu, the tangata whenua, were reduced to subsistence.

Their rangatiratanga denied; their future both tribally and individually bleak; their Treaty rights ignored. All this with the knowledge or connivance of successive governors acting on behalf of the Crown. 47

The Crown was equally culpable when it came to protecting mahinga kai or food gathering places. Its agents failed to understand the working of the Ngai Tahu domestic economy and the importance of rivers, streams, lagoons and wetlands. In spite of repeated protests they failed to set aside sufficient reserves to protect these special taonga. As a

44 Waitangi Tribunal 1991:174.

45 Waitangi Tribunal 1991:xv.

46 Waitangi Tribunal 1991:828.

47 Waitangi Tribunal 1991:830. 


\section{ABORIGINAL HISTORY 1995 19:1}

result farming, drainage, public works, pollution and the introduction of exotic fish and birds diminished the quality and quantity of food resources. Had Ngai Tahu been granted a place in decision-making, many of these problems could have been prevented. The Tribunal found that the reserves were inadequate to protect mahinga kai and provide Ngai Tahu with a base to participate in the larger economy. 48

\section{The Climate for Negotiations}

The ethos and the wairua of the Waitangi Tribunal and the cumulative impact of its reports were significant parts of a larger configuration which stressed co-operation and negotiation and a common search for truth rather than adversarial styles of challenge and falsification. The Court of Appeal and a number of government departments responded positively when Treaty issues were placed on their agenda. ${ }^{49}$ The Judges of the Court of Appeal examined the texts of the Treaty and all available reports of the Waitangi Tribunal and drew on parallel experience in Canada and the United States of America before setting out their 'Principles of the Treaty of Waitangi'. These stressed partnership, consultation and reasonable co-operation and underscored the need for the Pakeha and Maori Treaty partners 'to act towards each other reasonably and with the utmost good faith'. 50 The Lange Government, in July 1989, formalised its response when it published 'Principles for Crown action on the Treaty of Waitangi' setting out the Crown's obligations to govern and at the same time recognising rangatiratanga, equality, co-operation and a responsibility to redress grievances. 51

As the Ngai Tahu hearings proceeded it became clear that Crown and claimants had each taken up the challenge implicit in the new style of working. Each party recognised and affirmed the integrity of the other: the mana of Ngai Tahu was carefully balanced against the honour of the Crown. Ngai Tahu produced a team of counsel and researchers who were strongly bicultural and the Crown actively pursued a policy of presenting all of the evidence which its researchers were able to uncover. None of this precluded concurrent actions in the courts over fishing rights, vigorous Ngai Tahu defence of its northern boundaries in the face of tribal cross claims or testy exchanges between claimants and Crown when there were disagreements on topics such as the definitions of 'fisheries' and 'mahinga kai'. Overall the wairua of the Tribunal and the various marae prevailed: the extended family of those who were part of the hearings for 27 months travelled together, lived together and held together. The stage was set for the Tribunal to continue and refine a style of working initiated with the Muriwhenua Fisheries Report (1988). The Tribunal would report on grievances; $i w i$ and Crown would negotiate remedies.

The Ngai Tahu Report, as discussed above, provides a framework for detailed, face to face negotiations involving a number of different agencies of government. On the Crown side negotiations are carefully co-ordinated by a Crown Task Force on Waitangi Issues convened by the Minister of Justice and including the Attorney-General and the Ministers of Finance, State Owned Enterprises and Maori Affairs. ${ }^{52}$ On the Ngai Tahu side the Ngai Tahu Maori Trust Board negotiates on behalf of Ngai Tahu iwi and hapu.

48 Waitangi Tribunal 1991:Chapter 17.

49 New Zealand Court of Appeal 1987; Parliamentary Commissioner for the Environment 1988; Committee on a Maori Perspective for the Department of Social Welfare 1986; Royal Commission on Social Policy 1988.

New Zeland Court of Appeal 1987:44; Renwick 1990:56-61.

Department of Justice 1989; Renwick 1990:127-133.

52 Renwick 1990:132-3. 


\section{RECLAIMING LAND: THE WATTANGI TRIBUNAL}

With sea fisheries the subject of separate, multi-tribal negotiations, the main focus moved to land and mahinga kai; on reservations never made and purchases inadequately paid for. In the words of Judge Ashley McHugh in his closing address, the Tribunal has avoided 'specific recommendations as to the quantum of compensation payable or parcels of land that should be returned to Maori ownership'.53 It has, instead, been very intentional in providing a number of examples which make it very clear to the Crown, the claimants and the public at large, the order of magnitude of the injustices involved. In the Otakau block, for example, the Ngai Tahu residents were left with less than 30 acres per head. By contrast pakeha settler John Jones was awarded 11,060 acres after prolonged dispute. Averaged over himself, his wife and their nine children, this represented more than 1000 acres per head. 54 At a more global level the 12.5 acres per head reserved for Ngai Tahu is compared with the 1133 acres per head which would have met guidelines used by the New Zealand Company in its pre Treaty publicity. 55

\section{Negotiations Proceed/Negotiations are Suspended}

Negotiations between Ngai Tahu and the Bolger National Government proceeded during 1992 and 1993. The parties were moving towards a settlement of the claim when the 1993 Elections intervened. The Bolger Government remained in power but its majority was substantially reduced and the electorate had voted for a system of Mixed Member Proportional Representation to take effect from the following election. Government reassessed the ability of the Crown to pay compensation and published proposals to introduce a Fiscal Envelope which would cap the national total of Treaty Settlements at \$1 billion. ${ }^{56}$ Ngai Tahu, with the largest claim, would be most affected. The Government also reshaped its negotiating teams.

Negotiations slowed during 1994 and were suspended when Ngai Tahu rejected an interim offer by the Crown. At that point Ngai Tahu requested the Tribunal to reconvene and went to the Courts to prevent the Government from disposing of Crown Forestry and other assets. The political climate has changed in the short term and it is not clear when or if negotiations for a Ngai Tahu Settlement will be resumed.

\section{The Waitangi Tribunal: an Assessment}

The year 1993, ten years after the publication of the Motunui Report, provided an appropriate date to overview the working of the Waitangi Tribunal. It had firmly established itself as an even handed, accessible and patient forum for Maori grievances to be explored in depth and in detail. At every point the Tribunal has been meticulous in weighing up the evidence brought to it by claimants and Crown. Its own researchers, staff and commissioned, have widened the pool of knowledge and it has been open to receive the evidence and listen to the concerns of other parties. At every point it has recognised that the Treaty of Waitangi, signed in many different places over a period of eight months in 1840 , was a compact between Crown and iwi. All of its internal procedures and each of its published reports are based on the recognition that the honour of the Crown and the mana of the $i w i$ must each be affirmed by the outcomes of the claims process.

During the period under review the Tribunal has worked biculturally drawing widely on the political skills and the day to day courtesies of both cultures. It has animated a process

\footnotetext{
53 Waitangi Tribunal 1991:1219.

54 Waitangi Tribunal 1991:43.

55 Waitangi Tribunal 1991:829.

56 Office of Treaty Settlements 1994.
} 


\section{ABORIGINAL HISTORY 1995 19:1}

which has drawn together a great diversity of people with a wide range of historical, legal, cultural, scientific and practical skills. It has drawn evenly on both cultures and endeavoured to avoid any suggestion that the insights or priorities of one culture should give ground to those of the other culture. It has frequently tapped in to the pool of good will available in both cultures and mostly, but not always, avoided head on collisions with the ill will that has accumulated during 150 years of uneven development.

The fact that the Tribunal is unable to make binding recommendations has proved to be one of its strengths. Its impact is the result, not of its legal authority but its skills of analysis and synthesis and its ability to cumulate historical and legal evidence. ${ }^{57}$ It has drawn on legal insights and precedents from Canada and the United States of America. Equally important, it has used an awareness of Canadian process to affirm ways of working which seemed to it to be culturally appropriate in the New Zealand context. Its main strengths have come out of process and performance. Its wairua has expanded and its mana consolidated with each successive hearing.

The Maori language title of the Waitangi Tribunal is Te ropu whakamana te Tiriti. Its achievements redirect New Zealand, Crown and people, to the partnership inherent in that founding document. The Waitangi Tribunal identifies injustice and unravels grievances, but its intention is not to dwell on the past. To use the words of Edward Taihakurei Durie, it enables us 'to move beyond guilt and ask what can be done now and in the future'. The Treaty is seen as a living document, always speaking. The ethos of the Tribunal is '(to release) the Treaty to the Modern World, where it begs to be reaffirmed, (to unshackle it) from the ghosts of an uncertain past'. 58

\section{A 1995 Perspective}

The future of the Treaty settlement process is still uncertain. Government has recently completed a direct settlement with Tainui in the North Island but progress with Tribunal claims has slowed to the point where the mana of the Tribunal and the honour of the Crown are at risk. The Waitangi Tribunal is now seriously underresourced and understaffed. The Fiscal Envelope proposals have been widely rejected by Maori but reconfirmed in the 1995 Budget.

In this context $i w i$ are biding their time and weighing up their options; awaiting the outcome of elections in 1995 or 1996 and preparing, if necessary, to move away from Tribunal and negotiating table into the Courts.

\section{Editor's Note, November 1996.}

The political situation in New Zealand changed when the formation of a United Party gave the Bolger government a clear majority for the remainder of its term. Negotiations between the Crown and Ngai Tahu resumed in June 1996 and an Agreement-in-Principle was signed on October 4th, seven days before the 1996 General Election. The agreement is a basket of remedies involving land, cash, co-management, place names and a formal apology by the Crown.

57 cf. Renwick,1990:136; Stokes 1992:182-184.

58 Waitangi Tribunal 1987:86 cited by Renwick 1990:135; Royal Commission on Social Policy 1988:3, 1, 79-127. 


\section{RECLAIMING LAND: THE WAITANGI TRIBUNAL}

\section{LIST OF REFERENCES}

Awatere, D. Maori Sovereignty. Broadsheet, 1984.

Bellich, J. The New Zealand Wars, 1986.

Berger, T.R. Northern frontier, northern homeland: the report of the Mackenzie Valley Pipeline Inquiry. Ministry of Supply and Services, Canada, 1977.

Binney, J., Bassett, J. and Olssen, E. The people and the land: te tangata me te whenua Allen and Unwin. Wellington, 1990.

Committee on a Maori Perspective on the Department of Social Welfare, Puao-te-ata-tu (day break), 1986.

Cumberland, K.B. A Land Despoiled: New Zealand about 1838. New Zealand Geographer, 6, 1:13$34,1950$.

Department of Justice. Principles for Crown Action on the Treaty of Waitangi, 1989.

Evison, H.C. Ngai Tahu Land Rights, 1986.

(ed.) The Treaty of Waitangi and the Ngai Tahu Claim, 1988.

Hight, J. and Straubel, C.R. A History of Canterbury. Volume 1 to 1854, Whitcombe and Tombs. Christchurch, 1957.

Kawharu, I.H. (ed.) Waitangi: Maori and Pakeha Perspectives on the Treaty of Waitangi. Oxford University Press, 1989.

New Zealand Court of Appeal. The New Zealand Maori Council and Latiner v Attorney-General and Others, 6411 NZLR; 6 NZAR 353 (CA), 1987.

New Zealand Law Commission. The Treaty of Waitangi and Maori Fisheries. Preliminary Paper Nol 9, 1989.

Office of Treaty Settlements. Crown Proposals for the Settlement of Treaty of Waitangi Claims, 1994.

Oliver, W.H. and Williams, B.R. (eds) The Oxford History of New Zealand. Oxford University Press, 1981.

Oliver, W.H. Claims to the Waitangi Tribunal. Waitangi Tribunal and Daphne Brasell Press, 1991.

Orange, C. The Treaty of Waitangi. Allen and Unwin, 1987.

. The Treaty of Waitangi: A Historical Overview', Resource Management Seminar Series on Public Sector 11, 4:2-6, 1988.

. The Story of a Treaty. Allen and Unwin, 1989.

. An Illustrated History of the Treaty of Waitangi. Allen and Unwin. Wellington, 1990.

O'Regan, T. Mana Whenua: The Natural World of the Maori. TVNZ Documentary, 5 episodes, 1987.

The Ngai Tahu Claim, in Kawharu, I.H., Maori and Pakeha Perspecives on the Treaty of Waitangi, 234-262: 1989.

Orbell, M. The Natural World of the Maori. Sheridan House, 1985.

Parliamentary Commissioner for the Environment. Environmental Management and the Principles of the Treaty of Waitangi, 1988.

Regina v White and Bob (1964), 52 WWR 193, 50 DLR (2nd) 613 (BCCA).

Renwick, W. The Treaty Now. GP Books, 1990.

Report of the Ministerial Advisory Committee on a Maori Perspecive for the Department of Social Welfare (1986), Puao-Te-Ata-Tu.

Reynolds, T. The Treaty - what went wrong and what are we doing about it? N.Z. Geographic, 5:32-73, 1990.

Rice, G.W. The Oxford History of New Zealand. Oxford University Press, 1992.

Royal Commission on Social Policy (1988), The April Report, 3 volumes.

Sinclair, D. Land Since the Treaty: The Nibble, the Bite, the Swallow, in King, M. (ed.), Te Ao Hurihuri: The World Moves on. Longman Paul, 107-128, 1975.

Sorrenson, M.P.K. Towards a Radical Interpretation of New Zealand History: The Role of the Waitangi Tribunal. The New Zealand Journal of History 21, 2:173-188, 1987.

Sparrow v Regina. 2 WWR (1987) 577-609 (BCCA), 1986. 


\section{ABORIGINAL HISTORY 1995 19:1}

Stirling, A.M. Amiria: The Life Story of a Maori Woman (as told to Anne Salmond). Heinemann Reed. Auckland, 1976.

Stokes, E. 'The Treaty of Waitangi and the Waitangi Tribunal', Applied Geography 12, 2:176$191,1992$.

Temm, P. The Waitangi Tribunal: the conscience of the Nation. Random, 1990.

Te Weehi v Regional Fisheries Officer. 1 NZLR 680 and 6 NZAR 114, 1986.

Waitangi Tribunal . Waiau Pa Report. 1978a

. Fisheries Regulations (Hawke). 1978b.

. Motunui-Waitara Repon, 1983.

. Kaituna River Report, 1984.

. Manukau Report, 1985.

- Te Reo Maori, 1986.

- Orakei Report, 1987a.

- Waiheke Island Report, 1987b.

. Muriwhenua Fishing Report, 1988.

- Ngai Tahu Report, 3 volumes, 1991.

- Ngai Tahu Fisheries Report, 1992a.

. The Fisheries Settlement Reort, $1992 \mathrm{~b}$.

. Ngai Tahu Ancillary Claims Report, 1995.

Walker, R. Ka whawahi tou matou: Struggle without end. Penguin Books, 1990. 


\section{RECLAIMING LAND: THE WATTANGI TRIBUNAL}

\section{Appendix 1. Maori and English Texts of Te Tiriti o Waitangi}

\section{Te Tiriti}

KO WIKITORIA, te Kuini o Ingarani i tana mahara atawai ki nga Rangatira me nga Hapu o Nu Tirani i tana hiahia hoki kia tohungia ki a ratou o ratou rangatiratanga me to ratou wenau, a kia mau tonu hoki te Rongo ki a ratou me te Atanoho hoki kua wakaaro ia he mea tika kea tukua mai tetahi Rangatira-hei kai wakarite ki nga Tangata maori o Nu Tiranikia wakaaetia e nga Rangatira maori te kawana-tanga o te Kuini ki nga wahikatoa o te wenua nei me nga motu-na te mea hoki he tokomaha ke nga tangata o tona Iwi Kua noho ki tenei wenua, a e haere mai nei.

Na ko te Kuini e hiahia ana kia wakaritea te Kawanatanga kia kau ai nga kino e puta mai ki te tangata Maori ki te Pakeha a noho ture kore ana.

$\mathrm{Ng}$, kua pai te Kuini kia tukua a hau a Wiremu Hopihona he Kapitana i te Roiara Nawi hei Kawana mo nga wahi katoa o Nu Tirani a tukua aianei amua atu ke te Kuini e mea atu ana ia ki nga Rangatira o te wakaminenga o nga hapu o Nu Tirani me Rangatira atu enei ture ka korerotia nei.

\section{Ko te Tuatahi}

Ko nga Rangatira o te wakaminenga me nga Rangatira katoa hoki ki hai i uru ki taua wakaminenga ka tuku rawa atu ki te Kuino o Ingarani ake tonu atu-te Kawanatanga katoa o o ratou wenua.

\section{Ko te Tuarua}

Ko te Kuini o Ingarani ka wakarita ka wakaae ki nga tangata katoa o Nu Tirani te tino rangatiratanga o o ratou kainga me o ratou taonga katoa. Otiia ko nga Rangatira o te wakaminenga me nga Rangatira katoa atu ka tukuiki te Kuini te hokonga o era wahi wenua e pai ai te tangata mona te Wenua-ki te ritenga o te utu e wakaritea ai e ratou ko te kai hoko e meatia nei e te Kuini hei kai hoko mona.

\section{Ko te Tuatoru}

Hei wakaritenga mai hoki tenei mo te wakaaetanga ki te Kawana-tanga o te Kuini-Ki tiakina e te Kuini o Ingarani nga tangata maori katoa o Nu Tirani ka tukua ki a ratou nga tikanga katoa rite tahi ki ana mea ki, nga tangata o Ingarani.

(signed) WILLIAM HOBSON Consul and Leiutenant-Governor

Na ko matou ko nga Rangatira o te Wakaminenga o nga hapu o Nu Tirani ka huihui nei ki Waitangi ko matou hoki ko nga Rangatira o Nu Tirani ka kite nei i te ritenga enei kopu ka tangohia ka wakaaetia katoatia e matou, koia ka tonungia ai o matoa ingoa o matou tohu.

Ka meatia tenei ki Waitangi i te ono o nga ra Pepueri i te tau kotahi mano, e waru rau e wa te kau o to tatou Ariki.

Ko nga Rangatira o te wakaminenga.

\section{Treaty of Waitangi Amendment 1985, Schedule}

\section{The Treaty}

HER MAJESTY VICTORIA, Queen of the United Kingdom of Great Britain and Ireland, regarding with Her royal favour the Native Chiefs and Tribes in New Zealand, and anxious to protect their just rights and property, and to secure to them the enjoyment of peace and good order, has deemed it necessary, in consequence of the great number of Her Majesty's 


\section{ABORIGINAL HISTORY 1995 19:1}

subjects who have already settled in New Zealand, and the rapid extension of emigration both from Europe and Australia which is still in progress, to constitute and appoint a functionary properly authorized to treat with the Aborigines of New Zealand for the recognition of Her Majesty's sovereign authority over the whole or any part of those Islands. Her Majesty, therefore, being desirous to establish a settled form of Civil Government with a view to avert the evil consequences which must result from the absence of necessary laws and institutions, alike to the Native population and to Her subjects, has been graciously pleased to empower and authorise me, William Hobson, a Captain in Her Majesty's Royal Navy, Consul and Lieutenant-Governor of such parts of New Zealand as may be or hereafter shall be ceded to Her Majesty, to invite the confederate and independent Chiefs of New Zealand to concur in the following articles and conditions:-

\section{Article the First}

The Chiefs of the Confederation of the United Tribes of New Zealand, and the separate and independent Chiefs who have not become members of the Confederation, cede to Her Majesty the Queen of England, absolutely, and without reservation, all the rights and powers of sovereignty which the said Confederation of individual Chiefs respectively exercise or to possess, over their respective territories as the sole sovereigns thereof.

\section{Article the Second}

Her Majesty the Queen of England confirms and guarantees to the Chiefs and Tribes of New Zealand, and to the respective families and individuals thereof, the full, exclusive, and undisturbed possession of their lands and estates, forests, fisheries, and other properties which they may collectively or individually possess, so long as it is their wish and desire to retain the same in their possession; but the Chiefs of the United Tribes and the individual Chiefs yield to Her Majesty the exclusive right of preemption over such lands as the proprietors thereof may be disposed to alienate, at such prices as may be agreed upon between the respective proprietors and persons appointed by Her Majesty to treat with them in that behalf.

Article the Third

In consideration thereof, Her Majesty the Queen of England extends to the Natives of New Zealand Her royal protection, and imparts to them all the rights and privileges of British subjects.

W. HOBSON Lieutenant Govemor.

Now, therefore, we, the Chiefs of the Confederation of the United Tribes of New Zealand, being assembled in congress at Victoria, in Waitangi, and we, the separate and independent Chiefs of New Zealand, claiming authority over the tribes and territories which are specified by our respective names, having been made fully to understand the provisions of the foregoing Treaty, accept and enter into the same in the full spirit and meaning thereof; in witness of which we have attached our signatures or marks at the places and the dates respectively specified.

Treaty of Waitangi Act 1975, First Schedule 


\section{RECLAIMING LAND: THE WAITANGI TRIBUNAL}

\section{Appendix 2. Kaituna Report Recommendations, 1984}

10.1 TO THE HONOURABLE THE MINISTER OF MAORI AFFAIRS THAT notice be taken of the Finding of this Tribunal that the policy of the Crown by which a pipeline is to be constructed to discharge effluent from the Rotorua District Council Waste Water Treatment Plant into the Kaituna River is contrary to the principles of the Treaty of Waitangi.

10.2 TO THE HONOURABLE THE MINISTER OF WORKS AND DEVELOPMENT

10.2.1 THAT the policy of the Crown by which a pipeline is to be constructed to discharge effluent from the Rotorua District Council Waste Water Treatment Plant into the Kaituna River be abandoned as being contrary to the principles of the Treaty of Waitangi,

AND

10.2.2 THAT research be undertaken into the possibility of disposing of such effluent by discharging the same on the land in a suitable and practical manner instead of discharging the same into Lake Rotorua, AND

10.2.3 THAT the Water and Soil Conservation Act 1967 and related legislation be amended to enable Regional Water Boards and the Planning Tribunal properly to take into account Maori spiritual and cultural values when considering applications for grant of water rights, the renewal thereof or objections to such applications.

10.3 TO THE HONOURABLE THE MINISTER OF WORKS AND DEVELOPMENT

and

\section{TO THE HONOURABLE THE MINISTER OF HEALTH}

10.3.1 THAT the present subsidy granted for the Kaituna River Major Scheme be altered to enable the Rotorua District Council to treat the effluent from its Waste Water Treatment Plant by a suitable biological or chemical stripping process without loss of that subsidy so that phosphorus and ritrogen can be removed from that effluent up to the standard required by the water right now granted permitting the District Council to discharge such effluent into Lake Rotorua.

10.4 TO THE HONOURABLE THE MINISTER IN CHARGE OF THE PARLIAMENTARY COUNSEL'S OFFICE

10.4.1 THAT the attention of the Chief Parliamentary Counsel and other appropriate officers be drawn to the Finding of this Tribunal with particular reference to the consequences of legislation being enacted that is in conflict with the principles of the Treaty of Waitangi.

DATED at Wellington this 30th day of November 1984.

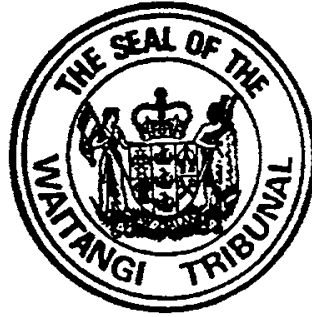

THE SEAL OF

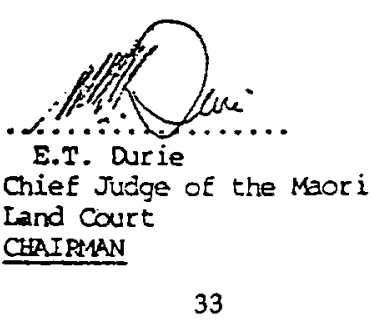

33
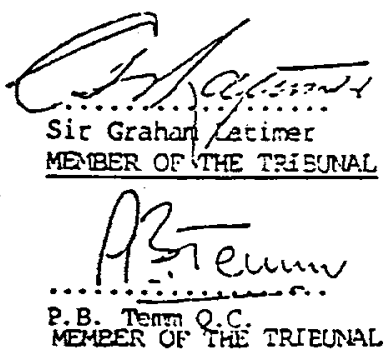

THE WAITANOI TMIEUNAL 
ABORIGINAL HISTORY 1995 19:1

\section{Appendix 3. Glossary}

\begin{tabular}{|c|c|}
\hline Aotearoa & New Zealand \\
\hline hapu & subtribe \\
\hline iwi & tribe or people \\
\hline kaitiaki & guardians \\
\hline kaitiakitanga & guardianship, environmental decisionmaking \\
\hline kaumatua & elder \\
\hline kawanatanga & governorship \\
\hline mahanga kai & food gathering places \\
\hline mana & authority, identity, prestige \\
\hline manawhenua & authority in relation to land and resources \\
\hline marae & meeting place \\
\hline pakeha & European New Zealanders \\
\hline pounamu & greenstone or jade \\
\hline rangatira & chief of an iwi or hapu \\
\hline rangatiratanga & tribal authority exercised through rangatira \\
\hline rohe & district or tribal domain \\
\hline Tane & God of the forests \\
\hline Tangaroa & God of the seas \\
\hline tangata whenua & people of the land, Maori \\
\hline taonga & treasures \\
\hline tauiwi & non Maori \\
\hline tino rangatiratanga & full tribal authority \\
\hline Tiriti & Treaty \\
\hline wairua & spirit \\
\hline whanau & family \\
\hline
\end{tabular}

